European Journal of Accounting, Auditing and Finance Research

Vol.10, No. 1, pp.1-24, 2022

Print ISSN: 2053-4086(Print),

Online ISSN: 2053-4094(Online)

\title{
DETERMINANT OF AUDIT QUALITY IN POST IFRS AND 2018 CODE OF CORPORATE GOVERNANCE: EVIDENCE FROM NIGERIA
}

\author{
Emeka-Nwokeji, N. A.(Ph.D), ${ }^{1}$ Prof Okoye, E. I., ${ }^{2}$ Chiedu, Christian O. ${ }^{3}$ Agubata, Stella N. \\ ${ }^{1,4}$ Department of Accountancy, Chukwuemeka Odumegwu Ojukwu University Igbariam \\ Campus, Anambra State Nigeria
}

${ }^{2}$ Department of Accountancy, Nnamdi Azikiwe University, Awka, Anambra State.

${ }^{3}$ Department of Accountancy, Delta State Polytechnic, Ogwashi-Uku Delta State, Nigeria.

\begin{abstract}
Audit quality is an issue of great concern in dealing with the confidence and credibility crisis that has engulfed the investment scene following collapse of many firms around the world as a result of outright fraud or fraudulent financial reporting. The study used panel data approach to investigate determinant of audit quality of firms listed in Nigerian Stock Exchange. Positivist research paradigm and Ex post facto research design was adopted. Thus secondary data was collected from sample of 14 firms purposively selected from non-financial firms from 2012 to 2019 resulting to 112 firm specific observations. Audit quality measured by accrual quality developed by Dechow and Dichev 2002 is the dependent variable. Audit fee, audit independence, audit switching, audit effectiveness (audit firm size) constitute the independent variables. Result of the study revealed that about eleven percent variation in the audit quality of sampled firms was jointly explained by the independent variables used in the study. The beta coefficient of the variables showed that audit fee, audit independence, audit switching and audit effectiveness (audit firm size) is negative but not significant in influencing accrual level. This indicates that the independent variables by reducing accrual level increases audit quality. The study concluded that audit fee, audit independence, audit switching and audit effectiveness by reducing accrual level has positive but insignificant effect on audit quality of selected firms. The study affirms Agency theory that managers opportunistic behaviour can be reduced by a third party employed by the owners. The study among other things recommended that firms should review their policies particularly as it concerns their external auditors to ensure that there are no familiarity threats, real or perceived conflict of interest that will undermine their independence in carry out their services. there is also need to enforce recent regulations toward audit firm rotation or switching after the ten years' period specified in the 2018 Code of corporate governance in order to reduce information risk and enhance audit quality.
\end{abstract}

KEYWORDS: determinant, audit fee, independence, audit switching, audit effectiveness, capital market, IFRS

ECRTD-UK: https://www.eajournals.org/

ULR: https://doi.org/10.37745/ejaafr.2013 


\section{INTRODUCTION}

Audit failures around the world has brought a great deal of disappointment to stakeholders, investors and entire accounting and auditing profession. Disappointment and heartbreak following loss from fraud and corporate failures are better imagined than experienced. Corporate scandals and failures have raise doubt as to the credibility of audited financial statements, audit quality and independence of auditors. These have devastating effect on the economy as fund needed to stimulate economic growth and development will not come with most investors losing confidence on reported accounting figures. Recall reporting scandals that occurred in Cadbury Nigeria Plc; African Petroleum Plc; Savannah Bank and African International Bank; Wema Bank, Nampak, Finbank and Spring Bank and more recently Intercontinental Bank Plc., Bank PHB; Oceanic Bank Plc. and AfriBank Plc (in Nigeria). These firms were certified distressed by Central Bank of Nigeria CBN barely few months after their auditors had given them a clean bill of health through their audit report (Okaro \& Okafor,2013). Recall also financial reporting scandals in major corporations such as Enron and WorldCom in the United State of America as well as Parmalat in Italy. These scandals both in Nigeria and other parts of the world have brought public focus to the audit profession and the audit quality.

These corporate scandals are significant cause for concern as they have led to loss of confidence on reported figures. There has also been concerns about the possible lack of independence which arises from a long-standing professional relationship between auditors and their clients. An auditor getting too familiar with his client for a long period of time, increases the risk of audit failure Ayorinde \& Babajide, 2015). On the other hand, short term auditor-client relationships may also be associated with a high risk of audit failure due to an auditor's familiarity with a client and its operations. Meanwhile auditing services market has been scrutinized by a number of users of accounting information regarding audit remuneration. The amount paid for auditing services and the constant misrepresentation identified in the financial accounts are the main reasons for the scrutiny. As a result, it is thought that audit fees have a considerable impact on the auditor's loyalty to his client. Higher audit fees paid to external auditors may be expected to result in better audit services. Several studies have found that the fee paid to an external auditor has a positive impact others negative impact on audit quality. Some studies indicated increase in audit quality following auditor switches while others showed negligible or negative stock price changes. These events have drawn increased attention from both capital market participants, regulators and academic research. Thus ensuring quality of audited financial statement is vital not only to auditing profession but also to other users of financial statement.

Separation of ownership and management makes the concept of auditing an essential tool in public companies. Supporting this line of reasoning, AL-Qatamin and Salleh (2020), Okolie and Izedonmi (2014) and Abdullah, Ismail and Jamaluddin (2008) opined that auditing and corporate board are employed as a monitoring mechanism to reduce information asymmetries between managers and dispersed minority shareholders and to act as a first line of defense for shareholders' interest against aggressive management (Okaro \& Okafor, 2014). Continuing AL-Qatamin and

ECRTD-UK: https://www.eajournals.org/

ULR: https://doi.org/10.37745/ejaafr.2013 
Salleh (2020) noted that audit quality would make several stakeholders to determine their future relationship with firms. Management of firms are expected by law to prepare and present report to show financial performance, financial position and cash flow among others. This implies that Contents of the financial statements are corporate responsibility (Yuniarti, 2011). To prepare and report on firm's economic events, there are rules about how to prepare these reports, what to include in the reports, how items are valued, and what explanations to provide. Audit engagement provides report which gives an opinion on auditor's assessment of whether management's account of business' financial operations comply with required rules or standards. In the view of Olabisi, Kajola, Abioro and Oworu, (2020), audit deals with gathering and assessing evidence, which is the basis of forming an unbiased opinion on financial reports by an independent auditor that business correctly accounts for funds entrusted to it by owners. It provides confidence in the quality of financial reports prepared and presented by management. Audit is thus a mode of governance of an entity (Masood \& Afzal, 2016).

The purpose of an audit is to reduce information risk and enhance the degree of confidence of intended users in the financial statements. This is achieved by auditors gathering sufficient appropriate audit evidence in order to express an opinion on whether the financial statements prepared by management comply in all material respects with the applicable financial reporting framework. Auditing ensure that high quality financial accounting information is provided to investors. Audited financial statements exhibit high quality when it provides information with less earnings management; more conservatism in their accounting and lead to the greater value relevance (Gouiaa \& Zéghal, 2014). Commenting on the need to improve quality of audited financial statement, Masood and Afzal (2016) noted that audit quality is inevitable in bringing accountability and transparency in firms. Ensuring audit quality is as important as providing reliable and relevant accounting information. It is essential in maintaining investors' confidence on the accounting numbers provided in the financial statements. Audit quality means that information available to investors is devoid of material misstatement. It is mostly used to measure biasness in audited financial statement. Audit quality refers to matters that contribute to the likelihood that the auditor will achieve the fundamental objective of obtaining reasonable assurance, that the financial report as a whole is free of material misstatement; and ensure that material deficiencies detected are addressed or communicated through the audit report. In the face of resurgent pandemics and economic hardship, it is critical to give empirical evidence on the concept of audit quality.

Frequent accounting scandals both in Nigeria and other part of the world witnessed in this twentyfirst century is indication that audit quality and audit profession is not at an appropriate level. This brought public focus in general and researchers attention in particular to audit profession and the audit quality. It raised concern on what determines audit quality. Thus over the years, audit quality issue has been discussed and debated globally. Significant number of literature exists on the concept of audit quality using different research designs. Several actions have been taken by international agencies to address the audit quality issue. For example, government of United States introduced and enacted the Sarbanes-Oxley Act in 2002 and also established Center for Audit

ECRTD-UK: https://www.eajournals.org/

ULR: https://doi.org/10.37745/ejaafr.2013 
Quality in 2007 as steps to enhance the audit quality of audit profession and to enhance investor confidence and public trust in the capital markets.

Despite the increase in accounting and finance literature on audit quality, to date, there is limited current research on determinants of audit quality in Nigeria as a developing market following recent changes in the reporting and audit regulatory landscape in form of IFRS and The Code 2018. Federal Executive Council approved 1 January 2012 as the effective date for convergence of accounting standards in Nigeria with International Financial Reporting Standards (IFRS) for easier access to external capital as well as increase in foreign direct investment. Moreso, Financial Reporting Council of Nigeria in 2018 issued Nigerian Code of Corporate Governance hereafter referred as The Code to enhance the integrity of business environment and rebuild public trust and confidence in the Nigerian economy, thus facilitating increased trade and investment. The Code among other things emphasised that audit team should be independent of the company and to preserve independence, there should be a rotation of the audit engagement partner every five years. Also audit switch after a period of ten years is now mandatory. Thus this study employ data of firms following adoption of International Financial Reporting Standards which became effective from January 12012 and issuance of The Code in 2018 to assess determinants of audit quality. Also lack of consensus on few existing studies that relate to, audit fee, audit independence, audit switching and auditor type supports further studies using approaches different from extant studies.

This present empirical evidence seeks to fill this lacuna in extant literature from Nigeria as emerging economy. Thus the study examine what determines firms' ability to effectively limit financial statement manipulations through accrual level with particular reference to listed firms in Nigerian stock exchange. The study attempt to provide answers to the following questions: Does ability of the auditor to spot material misstatements and report the identified errors and omissions depend on fees paid for audit services, audit independence, audit switching and audit effectiveness measured with audit firm size. Specifically, the study investigates effect of four determinant variables of audit fee, audit independence, audit switching and audit size on audit quality of selected listed firms in Nigeria. This research is carried out by means of ex post facto research design using panel data approach from 2012 to 2019. Fixed effect model estimate was used in testing the hypotheses.

The findings of this research provides policy makers with valuable evidence to inform future policy in relation to improving audit quality. In recent years, there has been a growing call for evidence-based policy making that assesses the effects internal and external factors on audit quality of firms both from developed and developing economies. Understanding effect of audit switching, fee, independence and audit effectiveness (audit firm size) on audit quality is important as the evidence have far-reaching consequences for audit firms, audit partners, auditing profession and other stakeholders. The topic is timely for accounting researchers considering the continuing debate over mandatory auditor rotation sparked off Nigeria code of corporate governance 2018(The Code).

ECRTD-UK: https://www.eajournals.org/

ULR: https://doi.org/10.37745/ejaafr.2013 
In order to achieve the specified objectives, remainder of the paper is organised as follows: section 2 provides a review of concepts, recent studies on determinants of audit quality and hypotheses development. Section 3 describes methodology adopted in sourcing and analysing data. Section 4 summarizes the main empirical results. Section 5 concludes with a summary of the findings. Section 6 proffer recommendations based on the outcome of the study.

\section{Conceptual framework, Theoretical framework, Theoretical and Empirical Review}

Various concepts employed in the study, previous theoretical and empirical studies on determinants of audit quality are discussed under this heading.

\subsection{Conceptual framework}

In this research, the conceptual framework is to assess determinants of audit quality. Determinant variable was divided into four, namely: audit fee, audit independence, audit switching and audit effectiveness. While audit quality which is the dependent variable is a term used to describe audit activity performed by an independent auditor in compliance with auditing standards to ensure that the client entity complied with required reporting standards in preparing and reporting firms' economic events to reduce manipulations in the financial statement. This research also uses the size and age of the company as control variables to limit the influence of other factors on the audit The conceptual framework of this study is illustrated in figure 2.1 .

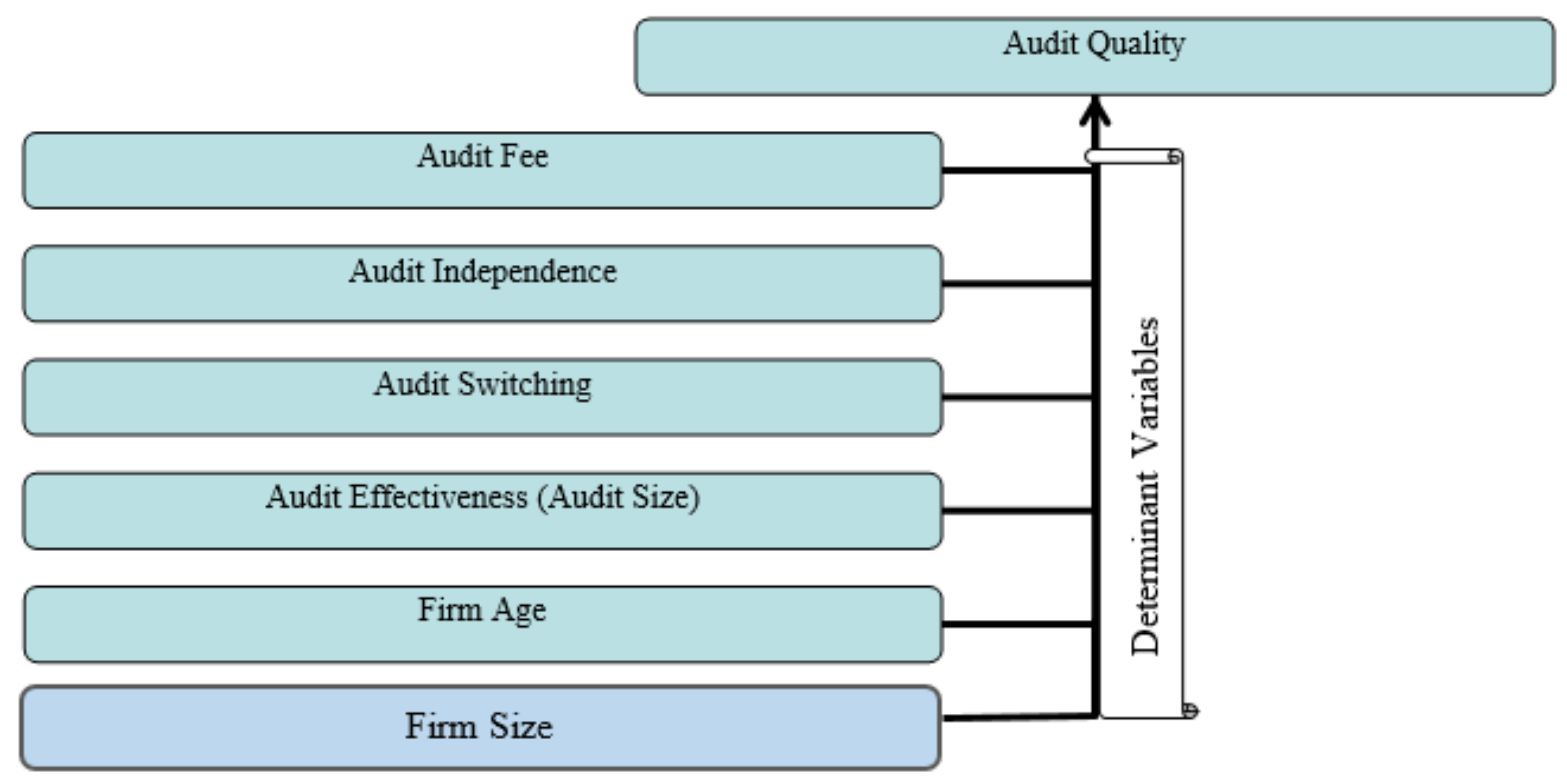

Figure 2.1 Conceptual Framework

\section{Concept of Audit Quality and Measures}

Audit quality means that information available to investors is devoid of material misstatement. Audit quality is mostly used to measure extent of biasness in audited financial statement. A

ECRTD-UK: https://www.eajournals.org/

ULR: https://doi.org/10.37745/ejaafr.2013 
measure for determining the degree of management bias in the financial statements that the auditor tolerated. Given multifaceted nature of audit quality, conceptualizing it is herculean task. The difficulty in conceptualising audit quality emanate from the fact that it is an intangible and unobservable attribute. Audit quality is a term used to describe audit activity performed by an independent auditor in compliance with auditing standards to ensure that the client entity complied with required reporting standards in preparing and reporting firms' economic events to reduce financial statement manipulations. It is used in describing an audit conducted in accordance with generally acceptable auditing standards which is likely to detect and report material misstatements in the financial statements. Audit quality is conceptualised in the words of Knechel, Krishnan, Pevzner, Shefchik \& Velury (2013) that audit quality depends much on whose eyes one looks through, either users, auditors, regulators or society. To user of financial reports high audit quality means the absence of material misstatements. The auditor conducting audit high audit quality means satisfactorily completing all tasks required by the firm's audit methodology. The audit firm may evaluate a high audit quality as one for which the work can be defended against challenge in an inspection or court of law. To regulators high quality audit is one that is in compliance with professional standards. Finally, society consider high quality audit to be one that avoids economic problems for a company or the market.

From the above description about audit quality, it means that the responsibility for performing quality audits of financial statements rests with auditors and it is obtained by virtue of an auditor's technical competence, independence, professional skepticism, lack of familiarity, experience among other factors. The above discussion prove that extant studies have used various proxies for audit quality. As observed by Jackson, Moldrich and Roebuk (2008), there is no perfect metric for measuring audit quality. Continuing, they assert that true audit quality is when the audit does not result in a type I or type II error - which means failing company being given an unqualified report or a non-failing company being given a qualified report. Simply put, audit quality means reduction in information risk. Effort is made in this paragraph to bring out the different measures of audit quality. Audit quality has been measured using a dichotomous variable of "ones" and "zeros", with one representing the use of big four auditors by the firm and zero representing use of non-big four (Ogoun \& Perelayefa, 2020; Aliu, Okpanachi \& Mohammed, 2018; Gouiaa \& Zéghal, 2014; Abdullah, Ismail \& Jamaluddin, 2008). Big four is a concept in auditing that refers to the four biggest audit firms in the worldwide auditing market. The four largest firms are: PriceWaterhouseCoopers (PwC), EY, KPMG, Deloitte. Total number of staff employed in audit firm has been used as a measure of audit quality in existing studies (Amahalu, \& Ezechukwu, 2017; Tobi, Osasrere \& Emmanuel, 2016). El-Dyasty and Elamer (2020) used discretionary accruals as proxy for audit quality. Similarly, Hoitash, Markelevich and Barragato (2007) employed absolute value of performance-adjusted discretionary accruals and an accruals quality measure developed by Dechow and Dichev (2002) to proxy for audit quality. The extent to which working capital accruals map into cash flow realizations, according to Dechow and Dichev (2002), is the best measure of accrual uncertainty. Similarly, extant literature measure audit quality through overall quality of financial reporting or earnings quality. Financial reporting quality uses such measures as discretionary accrual which are accruals that do not relate to normal

ECRTD-UK: https://www.eajournals.org/

ULR: https://doi.org/10.37745/ejaafr.2013 
operating activities, association between earnings and market returns as well as earnings conservatism (Behn, Choi \& Kang, 2008).

Accrual quality (level) is used in measuring audit quality in this study. Earnings quality which measure accrual quality developed by Dechow and Dichev (2002) is thus employed in this study in line with Hoitash et al (2007), as measure of audit quality. This audit quality measurement is based on the view that earnings, which are closer to cash flow, are better quality earnings. Discretionary accruals are accruals that do not relate to normal operating activities, and so a higher level of these accruals may indicate that management has been able to exert its power over the auditor by being able to report on terms favourable to management. DA falls under Rajgopal, Srinivasan and Zheng (2021) output-based proxies of audit quality. According to them, output based measures typically cover: material restatements, going concern opinions, financial reporting characteristics such as the use of discretionary accruals, the Dechow-Dichev measure of earnings quality or Basu's timely loss recognition measure among others.

\section{Concept of Determinant}

Determinant means factor which decisively affects the nature or outcome of something. It can be described as an element that identifies or determines the nature of something or that fixes or conditions an outcome. Determinant are a number of environmental or contextual factors, such as laws and regulations, corporate governance etcetera which have the potential to impact the nature and quality of financial reporting and directly or indirectly impact on audit quality. Crucean and Hategan, (2019) describe determinant as important concepts, elements and factors that influence another research topic. In the view of Ghebremichael (2018), determinant can also be describe as attributes and dimensions of a concept or variable. From the above it can be seen that understanding these factors, attributes or elements that influences or have consequences on the audit quality, are a great relevance both for the audit companies, regulators as well as for the users of the financial statements. Similarly, on the need to understand factors that affect audit quality, Hardiningsih, Januarti, Oktaviani, Srimindarti \& Udin (2019) noted that audit quality is very important because it involves the image of the auditor in the eyes of the public. It has been observed that several determinants, both internal and external, can affect audit quality, including auditor professional knowledge and skills; skepticism; independence, standards compliance; working conditions; audit duration and quality control.

Various measures have been used in extant literature as determinant variables. Olabisi, Kajola, Abioro and Oworu (2020), used audit fees, audit firm size, audit tenure, joint audit and audit independence as measure of determinant. Hardiningsih et al (2019) used competence; independence; professional skepticism; tenure audit; professional ethics to measure determinants of audit quality. From review of literature by Crucean and Hategan, (2019), determinant variables that affect audit quality are: auditor's rotation, auditor's mandate, information transparency both from the audited company and from the audit entities, audit fees, audit report form, opinion that an auditor issues after the analysis of the financial statements. Other factors identified from their

ECRTD-UK: https://www.eajournals.org/

ULR: https://doi.org/10.37745/ejaafr.2013 
study belong to corporate governance, audit committee, administrative structure and other committees. Audit fee and audit tenure was used to measure determinant variables in a study by (Oyedokun, Yunusa \& Adeyemo, 2018). Subianto (2018), used audit independence, professional skepticism, professional judgement and audit risk in measuring determinants of audit quality. Technical, functional, and independence dimensions were used by Ghebremichael (2018) in measuring determinants of audit quality. Mohammed and Joshua (2016) measured possible influencers of audit quality by grouping them into: supply-related factors and demand-related factors. According to them, demand factors also known as auditee characteristics includes client firm size, profitability, board-related characteristics, ownership and capital structure, among others. The supply-related factors also known as auditors' characteristics include auditor's independence, audit firm size, audit tenure, auditor rotation, auditors' reputation, audit industry expertise. In related studies, audit independence, audit fees, audit tenure, type of auditor, number of remarks in the audit report and audit firm size were used as measures of determinant of audit quality (Amahalu, Okeke \& Obi, 2017; Amahalu \& Ezechukwu; Leventis, Weetman \& Caramanis, 2005). Enofe, Mgbame, Efayena and Edegware (2014) used auditor independence, auditor experience, auditor accountability in measuring determinant variables. Enofe, Mgbame, Aderin and Ehi-Oshio (2013), used audit tenure, audit firm size, board independence and ownership structure in measuring determinant variable. Suyono (2012), measured determinant with independence, experience and accountability. This study proxy determinant with audit fee, audit independence, auditors switching and audit effectiveness (audit firm size).

\section{Theoretical Framework}

This section presents the existing theory upon which the study relies. This study is anchored on agency theory. Agency Theory is based on the relationship between the principal (owners) and the agent (managers). It is propounded by Jensen and Meckling (1976). Agency Theory proposes that as a result of separation between owners and managers (agents) in a limited liability companies, relationship existing between the principal (owners of business) and the manager as an agent is substantially difficult to create due to a conflict of interest. The mangers are likely to act in their best interest to the detriment of the owners. Thus a third party assurance on the report prepared and published by the managers is essential. Through appointment of third party (auditor) who provides assurance on the reported figures in the financial statements, verify the reliability of information in the company's report, information asymmetries that exist between managers and firm stakeholders is reduced. Third party assurance report by way of audit opinion reduces information risk and reduces management biasness in managing earnings. In this study the quality of the third party assurance will increase if the third party does not get too familiar with management by staying too long in the provision of audit service or undermine the independence through provision of non-audit services. Auditing is one of the most potent mechanisms for mitigating the large agency cost arising from the principal-agent contract arrangement and the attendant information asymmetry in public firms.

ECRTD-UK: https://www.eajournals.org/

ULR: https://doi.org/10.37745/ejaafr.2013 


\section{THEORETICAL AND EMPIRICAL REVIEW}

\section{Audit Fee and audit quality}

Researchers have for some time been curious regarding the effects of audit fees on the quality of the services rendered. Audit fees is payment to external auditor for providing auditing services to the client, it reflects the demand and supply factors associated with the audit services. In a most recent empirical study, Yuniarti, Novriela and Rahmadona (2021), used data of listed manufacturing firms in Indonesia Stock Exchange to assess whether audit fees and audit tenure has effect on audit quality. Result of logistic regression analysis show that audit fee has insignificant effect on audit quality. This indicates that audit fee has no effect on audit quality. Edtiyarsih, Sudaryati and Budisusetyo (2021) discovered that high audit fees have positive impact on audit quality. This indicate that Audit quality increases when the external auditor earns more audit fees. In a study on effect of audit quality and audit fees on the integrity of financial statements using listed firms in Indonesia, Serly \& Helmayunita (2019) discovered that audit fees have a positive effect on the integrity of financial statements. Their study indicates that with more audit fee, external auditors have resources at their disposal to gather evidence, verify and evaluate evidence to convince themselves of the integrity of the client's financial reports. Oyedokun, et al (2018) in their study on determinant of audit quality used data from industrial goods sector of Nigerian stock exchange. Analyses was done with panel regression and other diagnostic test. Results reveal that there is a negative relationship between audit fees and audit quality. Their study indicates that increased economic bonding between a client and the auditor reduces audit quality. Aliu et al (2018) investigated relationship between audit fees and audit quality using data of firms listed in the downstream sector of the Nigerian petroleum industry. Analyses was done with binary probit model estimation technique in addition to other diagnostic assumption tests. Results revealed that audit fee has significant negative relationship with audit quality. The indication of the result is that higher audit fees lead to a decline in audit quality.

\section{Audit independence and audit quality}

Being independent means to be objective and unbiased while performing professional services. Bello, Ahmad and Yusof (2018) noted that auditor's ability to exercise their responsibilities with a certain degree of independence is very critical to audit quality. Audit firms that are more independent are likely to offer services that add value to the client thereby offering more quality audit. Supporting this line of argument, Saputra (2015) and Haeridistia and Fadjarenie (2019) assert that quality of audit depends on auditor independence. Hence if the auditor's independence is doubtful, it can reduce quality of audit. Different measures have been used by extant studies to measure audit independence. According to Frankel, Johnson, and Nelson (2002), proportion of audit fees to non-audit fees have been used by researchers as a proxy for their independence. On the other hand, Iryani (2017), measure independence through length of relationship with clients; pressure from the client; review of the auditor counterpart and provision of non-audit services. Investigating the influence of auditor independence towards audit quality, Lamba, Seralurin, Lamba and Pattiasina (2020) employed quantitative approach. The results of the study show that auditor independence has a positive and significant effect on audit quality. Study by Soyemi, Olufemi and Adeyemi (2020) showed that auditor independence has positive and statistical

ECRTD-UK: https://www.eajournals.org/

ULR: https://doi.org/10.37745/ejaafr.2013 
significant effect on earnings management. This result indicates that auditor independence has direct association with earnings management, implying that higher fees, especially from one client, impair auditor independence, hence unable to detect material misstatements, thereby eroding audit quality. Mardijuwono and Subianto (2018) found that audit independence has insignificant effect on audit quality. This indicates that independence of the auditor does not guarantee that there will be increase in audit quality. Iryani (2017) provided empirical evidence that auditor's independence in conducting audit has a positive and significant effect on audit quality of firms in South Jakarta. This means that the higher the auditor's independence the higher the audit quality. Study by Octavia and Widodo (2015) showed that audit independence has significant and positive effect on audit quality. In a study on influence of auditor independence towards audit quality, Suseno (2013) discovered through survey design that auditor independence significantly influences the audit quality. The study indicates that enhancing auditing quality can be taken by means of developing independent attitudes.

\section{Audit switching and audit quality}

Auditor switching is a situation where a firm's external auditor is being replaced with a new one either by way of resignation or removal. Auditor switching also called audit firm rotation involve changing an audit firm carrying out audit assignment by the client. In the view of Aroh, Odum and Odum (2017) Audit switch has to do with the resignation, outright removal and the selection of a new auditor for the firm. It is a system of auditing that require companies to rotate their independent auditor periodically or after a specified number of years (Nawangsari \& Iswajuni, 2019; Liu \& Liu, 2008; Jackson et al 2008). The concept of auditor switching was sparked off after Enron and Authur Anderson Scandal of past two decades. Similarly, Section 20 (1\&4) of The Code recommended that external audit firms can no longer be retained for more than ten years continuously. Also in order to preserve independence, there should as well be rotation of the audit engagement partner every five years.

Commenting on the nature of auditor switching, Yanti and Wijaya (2020) and Stunda (2012) noted that auditor switching can be mandatory or voluntary. Auditor switching is mandatory when there is a change of auditors by the company because the regulations require the company to change its auditor within a certain period. On the other hand, voluntary auditor switching is an action taken by a company to replace its auditor when there are no regulations that require it to replace the auditor. The essence of auditor switching is to limit, if not to cut, the dependency of the auditors to their client. This means that auditor switching would prevent auditors from becoming too aligned with managers a situation that would impact on their independence (Febrianto, Dini, Audina, Yuskar \& Juita, 2017; Weiner, 2012; Jackson et al 2008). Tiamiyu, Bamidele and Soyemi (2019) measured auditor switching as a dichotomous variable of 1 where the firm changed auditor during the period and zero if otherwise. Similarly, Akrawah and Anichebe (2020) in a most recent study categorized auditors switching into downward switching and upward switching and used a dummy variable: "1" if auditor has been switched and " 0 ", if auditors have not been switched in line with (Chadegani, Mohamed \& Jari, 2011; Nazri, Smith, \& Ismail, 2012).

ECRTD-UK: https://www.eajournals.org/

ULR: https://doi.org/10.37745/ejaafr.2013 
Empirically, Fauziyah and Darmayanti (2021) investigated whether audit rotation with other variables have influence on audit quality of firms listed on the Indonesia Stock Exchange. The result of the analyses revealed that audit rotation has significant effect on audit quality. The result indicates that audit rotation is expected to increase the independence of the auditor. Yanti and Wijaya (2020) examined effect of auditor switching, audit fees, audit tenure and company size on audit quality using data from Indonesia Stock Exchange. The study revealed that auditor switching has no effect on audit quality. Hunt, Rosser and Rowe. (2020) examined whether increased switching of auditor is associated with audit quality. Result of the study revealed that companies that are more likely to switch auditors have a higher likelihood of misstatement and larger abnormal accruals. In a related research on whether audit selection regime affect audit market concentration in Nigeria Odesa and Agubata (2019) highlighted that audit switching has significant effect on audit market concentration in Nigeria. The study indicates that switching from audit firm to another significantly affect the audit market concentration in Nigeria. In a study by Amahalu, Egolum and Obi (2019) on effect of audit rotation on audit quality of quoted deposit money bank. Simple regression analyses conducted show that audit tenure has a significant positive effect on three measures of audit quality employed by the study. Febrianto et al (2017) investigated the influence of audit rotation on audit quality. Results of their study indicate companies that rotate their auditors mandatorily have higher audit quality than that of companies voluntarily rotating auditors. The study also reveals that switching among bigger accounting firms have the highest audit quality rather than switching between smaller audit firms. Kighir (2013) in a cross sectional research on the link between audit firm rotation and auditor independence, discovered that there is no significant relationship between audit firm rotation and auditor independence. Similar research by Onwuchekwa, Erah and Izedonmi (2012) on the link between mandatory audit rotation and audit independence using survey design. The result indicates that mandatory audit rotation has a positive relationship with auditor's independence. Jackson et al (2008) examines whether switching patterns of clients in their current voluntary switching capacity affect the levels of audit quality. The study finds that audit quality increases with audit firm rotation when audit quality is proxy by the propensity to issue a going concern opinion. However, auditor switching does not have an economically or statistically significant effect on audit quality, when measured by the level of discretionary accruals.

\section{Audit Effectiveness (Audit Firm Size) and audit quality}

Another issue of great concern in accounting literature is whether the judgments of big external auditors vary substantially from non-big auditors. Auditor size is mostly measured as an affiliation to Big 4 firms. Commenting on external auditors' effectiveness, Qawqzeh, Endut, Rashid and Dakhlallh (2020) observed that opinion of the external auditor enhances the confidence of all stakeholders and increase efficiency in the capital markets. In their view big audit firm is more likely to be competent and effective in encouraging their client firms to disclose more information regarding their activities. Citing Naslmosavi, Sofian and Saat (2013), they noted that quality and effectiveness of auditor opinion is an important issue, given that the statements must be relevant, reliable and useful to all the users. Thus big auditing firms exert influence against managers' opportunistic behavior. In their views, big 4 audit firms were assumed to have quality of audit services compared to non-big 4 audit firm. Supporting the argument for Big N auditors. Khurana

ECRTD-UK: https://www.eajournals.org/

ULR: https://doi.org/10.37745/ejaafr.2013 
and Raman (2004) cited in Rajgopal, Srinivasan and Zheng (2021) noted that there is general perception that Big $\mathrm{N}$ auditors provide a higher quality audit, given their scale of operation. Big $\mathrm{N}$ auditors have access to better resources, related to technology, training, and facilities. Continuing they added that Big $\mathrm{N}$ auditors are perceived to be more independent than smaller audit firms as they stand chance of suffering greater reputational risk should they be negligent. They rely less on client's revenues and are hence less likely to be influenced by an individual client. Also their larger revenue base exposes them to higher litigation risk. Big four is a concept in auditing that refers to the four biggest audit firms in the worldwide auditing market.

El-Dyasty and Elamer (2020) provided empirical evidence on effect of auditor type on audit quality using data from Egypt as an emerging market. The study utilized discretionary accruals as a proxy for audit quality. Result of the analyses revealed that Big 4 auditors has insignificant negative effect on discretionary accrual level. This result indicates that Big 4 auditors do not provide higher audit quality compare to their counterparts. Also Egyptian audit firms that affiliate with foreign audit firms has significant negative effect on accrual level used as measure of audit quality. This indicates that auditors that affiliate with foreign audit firms provide higher audit quality by mitigating earnings management. Similarly, Soyemi et al (2020) examined effect of audit firm size, audit tenure and audit independence in restricting incidence of accrual-based earnings management among quoted non-financial firms in Nigeria between 2008 and 2018. Result among others revealed that the larger the size of entities, the less managers are allowed to display opportunistic behaviour by deliberately manipulating earnings. Reguera-Alvarado, de Fuentes and Laffarga (2019) investigated whether external auditing through Big 4 (audit size), auditor specialization and long audit tenure variables reduces earnings managements and, if so, whether this relationship is affected by the economic crisis. Data of firms quoted on the stock markets over the period 2005-20094 in the US, the UK, Japan, Italy, France and Spain were used. Discretionary accrual was used to measure earnings management. Results showed that Big Four and auditor specialization helped to reduce earnings managements during the economic crisis. Dehkordi and Makarem (2011) examined effect of audit type and size on audit quality using firms selected from Tehran Stock Exchange (TSE) from 2002 to 2007. Discretionary accrual was used to represent audit quality. Results showed that financial statements audited by Big auditors which measured audit size has significant negative effect on accrual level. This indicate that auditor size is a factor constraining management ability to manage earnings. Geiger and Rama (2006) examined audit quality at Big 4 audit firms and non-big audit firms. The study utilized the accuracy of going concern opinion to measure audit quality. Result provided evidence that Big 4 audit firms outperform non-big audit firms.

\section{Assertions of the Study}

Above paragraphs of this study demonstrate that there is a growing literature from both developed and developing economies on different determinant variables that effect audit quality The studies revealed contradicting results about factors affecting audit quality. There is need to confirm the studies using data from firms in Nigeria particularly following recent changes in both reporting and auditing regulatory environment. The following assertions in their null form guide the study.

$\mathrm{H}_{\mathrm{ol}}$ : Audit fee has no significant effect on audit quality of selected firms in Nigeria.

ECRTD-UK: https://www.eajournals.org/

ULR: https://doi.org/10.37745/ejaafr.2013 
$\mathrm{H}_{02}$ : Audit independence has no significant effect on audit quality of selected firms in Nigeria.

$\mathrm{H}_{03}$ : Audit switching do not have significant effect on audit quality of selected firms in Nigeria.

$\mathrm{H}_{04}$ : Audit effectiveness (audit firm size) do not have significant effect on audit quality of selected firms in Nigeria.

\section{METHODOLOGY}

This study adopts ex-post facto design. The design employed is most suitable for the study since it helps in assessing determinants of audit quality using data of selected listed nonfinancial firms in Nigeria. Again the ex-post facto research design was employed because the events and data used have already occurred, implying that the variables were not manipulated by the researchers. Sample consists of 112 firm year observations derived from 14 selected non-financial firms with data available for eight years' period of 2012-2019. Data was collected from the audited annual reports of non-financial firms listed on the Nigerian Stock Exchange as at $31^{\text {st }}$ December 2019 which were purposively selected. Data was tested for normality using Shapiro-Wilks W normality test which confirmed the normality of data used in the study. Panel regression technique was used for analysis, with Hausman's test used in determining which of Fixed (FE) and Random effect (RE) analytical techniques is most appropriate. The panel modelling approach with its fixed effect and the random effect take care of drawback associated with the use of the pooled OLS. Specifically, the fixed-effect model was built to take study the causes of variations in an entity. Panel model approach takes care of both common and individual behaviours of groups. Apart from the regression analysis, descriptive analyses were carried out to describe the characteristics of dependent and independent variables employed in the study. The decision rule is to reject null hypothesis if P-value is less 0.05 significance level. Results were interpreted as statistically significant at 0.01 and 0.05 . All the analyses were done with the aid of STATA 13 software.

\section{Model Specification}

To capture determinants of audit quality of selected listed firms in Nigeria Stock Exchange, audit quality model was adopted from the work of Yanti and Wijaya (2020) on effect Auditor Switching, Audit Fee, Tenure Audit and Company Size on audit quality though with little modifications, which was stated functionally and econometrically as:

Audit Quality = f (Audit Fee, Audit Independence, Audit Switch, Audit Effectiveness, Controls)

AcrualLevit $=\beta 0+\beta_{1}$ AudFee $_{i t}+\beta_{2}$ AudInd $_{i t}+\beta_{3}$ AudSwit $_{i t}+\beta_{4}$ AudEffe $_{i t}+\mathrm{B}_{5} \mathrm{FSiz}_{\mathrm{it}}+\beta_{6} \mathrm{Fage}_{\mathrm{it}}+\mu$ it

ECRTD-UK: https://www.eajournals.org/

ULR: https://doi.org/10.37745/ejaafr.2013 
Where: Acrualev is the dependent variable, $\beta_{1}, \beta_{2}, \beta_{3}, B_{4}, B_{5} \beta_{6 i t}$ represents coefficients of the independent variables of audit fees, audit independence, audit switch, audit effectiveness, firm size and firm age. $\beta 0$ is the intercept of the regression also known as constant. $\mu$ represent the error term that is used to capture the variables that is not included in the model. The $i$ and $t$ are the crosssections and time, respectively.

Variables and Measurement

Variables

DEPENDENT VARIABLE

Audit Quality
Code

AcrualLev

\section{Measurement}

Accrual level developed by Dechow and Dichev 2002. Measures abnormal accruals as the residuals from regressions of changes in working capital on past, present, and forecasted future cash flows.

\section{INDEPENDENT VARIABLES}

Audit Fee

Audit Independence

AudInd

Audit Switching

AudSwi

Audit Firm Size (Audit

Effectiveness)

AudEffe

\section{CONTROL VARIABLES:}

Firm Size

FSiz

Firm Age

FAGE

\section{Empirical Results and Discussion of Findings}

Log of remuneration paid to Auditors for their audit and non-audit services.

Percentage is the audit fee or amount paid to auditors divided by revenue.

A dichotomous variable of " 1 " where the firm changed auditor during a particular period and " 0 " if otherwise.

Measured with Big 4 Auditors as a dichotomous variables of $(1,0)$,computed as "1" for Companies that use PWC, Delotte, $\mathrm{E} \& \mathrm{Y}$ and KPMG as external auditors and "0" otherwise

This section contains the analyses and interpretation of data collected for the study. Sample consists of 112 firm year observations derived from 14 selected non-financial firms with data available for eight years' period of 2012-2019. Table 4.1 shows a detailed description of the summary statistics of the variables used in the study. 


\section{Descriptive Statistics}

Descriptive statistics on Table 4.1 provides information regarding the characteristics of each variables in the model in terms of mean, standard deviation, minimum and maximum from 2012 to 2019. Audit quality of firms measured with accrual level of firms has a minimum and maximum values of 0.73 and 0.34 with an average value of -0.001 . The result indicates that most of the selected firms in the Nigerian Stock Exchange has low accrual level and invariably high earning and audit quality. This connotes a negligible presence of earnings management with a negative accruals level of -0.001 as average among sampled firms.

Table 4.1 Descriptive Statistics

\begin{tabular}{r|rrrrrrr} 
stats & Acrualev & audfee & audind & audswi & audeffe & fsiz & fage \\
-1 & & \\
mean & -.0018776 & 3.89374 & .3289732 & .1339286 & .4464286 & 6.785544 & 18.85714 \\
sd & .148815 & .486657 & .3766451 & .3421062 & .4993561 & .6457608 & 12.34552 \\
min & -.732 & 3 & .0439 & 0 & 0 & 5.5003 & 4 \\
max & .339 & 5.0812 & 1.9578 & 1 & 1 & 8.4957 & 46 \\
mean & -.0018776 & 3.89374 & .3289732 & .1339286 & .4464286 & 6.785544 & 18.85714 \\
skewness & -2.444853 & .324573 & 2.926315 & 2.149722 & .2155264 & .4183108 & .7981147 \\
kurtosis & 12.204 & 3.378139 & 11.40289 & 5.621306 & 1.046452 & 3.615053 & 2.236678 \\
N & 112 & 112 & 112 & 112 & 112 & 112 & 112
\end{tabular}

\section{Source: Extract from STATA Output}

This result is consistent with Soyemi et al (2020) that documented a mean value of 0.000 for discretionary accrual of quoted non-financial firms in Nigeria. Both results indicate very low level of earning manipulations among quoted non-financial firms and invariable higher audit quality. In the case of the explanatory variables, the mean values stood at 3.89, .32, 0.13, 0.44, 6.78, 18.90 for audit fee, audit independence, audit switching, audit credibility firm size and firm age respectively. The result showed that most sampled firms (54\%) do not employed the services of Big 4 audit firms. While $44 \%$ of the selected firms has Big4 auditors as their external auditors. Also about thirteen percent of selected firms changed their external auditors within the period of the study while about eighty-seven percent did not change their external auditors during the period of the study. This is not surprising considering that The Code was effective for only one year by 2019 that the data stopped. Much difference is not seen between the maximum (8.49) and minimum (5.50) values of firm size measured in terms of log of total asset. This reveals that majority of the firms included in the study are relatively of the same size. Average firm age of sampled firms is eighteen years. Oldest firm in the sample is 46years while some new firm that are 4 years are also part of the study as revealed by the maximum and minimum values of the firm age. The skewness result indicates that all the variables employed in the model are positively skewed audit quality. Which means that there are higher values above the sample mean. This result conforms with kurtosis result which shows that the data used in the study is leptokurtic since

ECRTD-UK: https://www.eajournals.org/

ULR: https://doi.org/10.37745/ejaafr.2013 
it has positive kurtosis with three out of the six variables (dependent and independent) having higher values above the value three (3) for a normal distribution.

\section{Normality Test}

Normality of data is often tested in order to ensure that the normality assumption of regression is satisfied. The data collected is first checked for normality and Shapiro-Wilks W normality test is adopted.

\section{Table 4.2 Normality Test}

\begin{tabular}{rrrrrr} 
Variable | & Obs & W & V & z & Prob $>\mathbf{z}$ \\
\hline Acrualev | & 112 & 0.74285 & 23.346 & 7.032 & 0.00000 \\
audfee I & 112 & 0.95442 & 4.138 & 3.170 & 0.00076 \\
audind I & 112 & 0.59302 & 36.949 & 8.057 & 0.00000 \\
audswi I & 112 & 0.90677 & 8.464 & 4.767 & 0.00000 \\
audeffe | & 112 & 0.99737 & 0.239 & -3.199 & 0.99931 \\
fsiz I & 112 & 0.94912 & 4.619 & 3.416 & 0.00032 \\
fage I & 112 & 0.85881 & 12.819 & 5.694 & 0.00000
\end{tabular}

\section{Source: Extract from STATA Output}

Shapiro-Walk test on Table 4.2 checks the normal assumption by constructing W statistic. W is positive and less than or equal to one. $\mathrm{W}$ being close to 1 indicate normality of the data (Henderson, 2006; Peng, 2004). With W test of $0.74,0.95,0.59,0.90,0.99,0.94$ and 0.85 , respectively for audit quality, audit fee, audit independence, audit switching, auditors' credibility, firm size and firm age respectively employed in the study being close to 1 , it indicates normality of the data. With this result, the study concludes that the data used are normally distributed, that there is no outlier in the data and thus analyses and conclusion therefrom are reliable for drawing conclusion.

\section{Regression Results}

Fixed Effect and Random Effect regression was conducted using data of firms selected for the study. Hausman's test was used to determine which of Fixed and Random effect analytical techniques is most appropriate for the purpose of making conclusion. Empirically, if the P-value of the chi-square of the Hausman Test is greater than $0.05(5 \%)$, the estimation based on the Random Effects will be better. However, if the P-value is less than 0.05 (5\%) estimation based on Fixed Effect will be better. Hausman tests conducted for the study revealed Chi2 of $\mathbf{2 6 . 9 0}$ and Prob>chi2(Probability-value) of $\mathbf{0 . 0 0 0 2}$ indicates that the fixed effect model is preferred and the result is presented and interpreted for this study. 
Table 4.3 Audit Quality Fixed Effect Regression Result

\begin{tabular}{|c|c|c|c|c|}
\hline Acrualev & | Coefficient & Std. Err. & $t$ & $P>\mid t$ \\
\hline audfee & -.1319645 & .1318187 & -1.00 & 0.319 \\
\hline audind & -.0923736 & .0781542 & -1.18 & 0.240 \\
\hline audswi & .0082316 & .0392053 & 0.21 & 0.834 \\
\hline audeffe & -.0733561 & .0458066 & -1.60 & 0.113 \\
\hline fsiz & -.0933683 & .1306897 & -0.71 & 0.477 \\
\hline fage & .0111936 & .0059861 & 1.87 & 0.065 \\
\hline constant & .9964668 & .8491438 & 1.17 & 0.244 \\
\hline $\begin{array}{l}\text { R-sq } \\
\text { F-Value (Prob }\end{array}$ & & $\begin{array}{l}=0.1152 \\
=2.00(0.0)\end{array}$ & & \\
\hline
\end{tabular}

\section{Source: Extract from STATA Output}

The $\mathrm{R}$-sqaured $\left(\mathrm{R}^{2}\right)$ result of fixed effect regression indicates that only about eleven percent (11\%) of the systematic variations in audit quality of selected non-financial firms in Nigerian Stock Exchange was jointly accounted for by audit fee, audit independence, audit switching, audit credibility and control variables of firm size (fsiz) and firm age (fage) used in the study. Other variables not employed in the study explains about eight nine percent of changes in audit quality. The F-value of 2.00 and its associated P-value of 0.07 shows that the regression model adopted by this study is appropriate.

The coefficients ( $\mathrm{p}$-value) for audit fee is $-0.092(0.24)$. This coefficient of variation ( $\beta$ ) which explains the direction of variability is negative while corresponding $\mathrm{p}$-values for audit fee is greater than $0.05(5 \%)$ showing that the variable do not have significant effect on audit quality. Thus null hypothesis that audit fee has no significant effect on audit quality of selected firms in Nigeria is accepted.

The coefficients (p-value) for audit independence is $-0.0131(0.32)$. This coefficient of variation $(\beta)$ which explains the direction of variability is negative while corresponding $p$-values for audit independence is greater than $0.05(5 \%)$ showing that the variable do not have significant effect on audit quality. Thus null hypothesis that audit independence has no significant effect on audit quality of selected firms in Nigeria is accepted.

The coefficients (p-value) for audit switching is $0.008(0.83)$. This coefficient of variation $(\beta)$ which explains the direction of variability is positive while corresponding p-values for audit switching is greater than $0.05(5 \%)$ showing that the variable do not have significant effect on audit quality. Thus null hypothesis that audit switching has no significant effect on audit quality of selected firms in Nigeria is accepted.

The coefficients ( $p$-value) for audit effectiveness is $-0.073(0.11)$. This coefficient of variation ( $\beta$ ) which explains the direction of variability is negative while corresponding $\mathrm{p}$-values for auditors' credibility is greater than $0.05(5 \%)$ showing that the variable do not have significant effect on audit

ECRTD-UK: https://www.eajournals.org/

ULR: https://doi.org/10.37745/ejaafr.2013 
quality. Thus null hypothesis that auditors' credibility has no significant effect on audit quality of selected firms in Nigeria is accepted.

Firm size employed as a control variable do not significantly affect audit quality of sampled firms in Nigeria Stock Exchange. However, the control variable of firm age has significant and positive effect on audit quality of selected firms over the period of the study.

\section{DISCUSSION OF FINDINGS}

Findings of the study revealed that audit fee has negative but insignificant effect on accrual level of selected firms. This indicates that the higher the total audit fees (remuneration) the lower the accrual level of firms and invariably increase in audit quality. The result suggests that an increase in audit fee by one percent will lead to about thirteen percent decrease in the accrual level and resultant increase in earning and audit quality by thirteen percent. It shows that if owners of the firm remunerate the auditors properly in consideration to audit efforts, time, and complexity of services provided, it will lead to stronger commitment, scrutiny and higher audit quality by exposing any form of window dressing by management. This result supports the finding by Yuniarti et al 2021 that audit fee has positive but insignificant influence on audit quality. It however contradicts the finding of Oyedokun et al (2018) and Aliu (2018) that audit fee reduces audit quality by increasing the economic bonding between the auditor and client.

Analyses of this study showed that audit independence increases audit quality by reducing accrual level though the effect is not significant. It showed that increase in audit independence by one percent will result to about nine percent increase in audit quality by reducing accrual level by nine percent. This supports theoretical findings by Bello et al (2018) noted that auditor's ability to exercise their responsibilities with a certain degree of independence enhances audit quality. It is similar to the finding of Mardijuwono and Subianto (2018) found that audit independence has insignificant effect on audit quality. The findings of this study however contradicts result by Octavia and Widodo (2015) that audit independence significantly and positively influences audit quality.

This study found that audit switching do not have significant effect on audit quality. Change in external auditors by one percent lead to a percentage increase in audit quality by reducing accrual level by one percent. This result is contrary to finding by Hunt et al (2020) that companies that are more likely to switch auditors have a higher likelihood of misstatement and larger abnormal accruals. The finding of this study is in line with Jackson et al (2008) that auditor switching does not have statistical significant effect on audit quality as measured by the level of discretionary accruals. Outcome of this current study confirms that mandatory changing of external auditors (audit switching) after every ten years is still new in Nigeria. Mandatory audit switch just became effective through 2018 code of corporate governance. Little wonder its effect on audit quality is insignificant.

ECRTD-UK: https://www.eajournals.org/

ULR: https://doi.org/10.37745/ejaafr.2013 
Audit Effectiveness (Audit firm size) revealed an insignificant negative effect on accrual level. This indicates that size of an audit firm has positive effect on audit quality but the effect is not significant. The result corroborates the finding of Soyemi et al (2020) that the larger the size of auditing firm, the less managers are allowed to display opportunistic behaviour by deliberately manipulating earnings. The study however negates the findings of El-Dyasty and Elamer (2020) that Big 4 auditors do not provide higher audit quality compare to their counterparts.

\section{CONCLUSION}

In this study, we provided empirical evidence of what determine firms audit quality. This study employed panel data of selected firms in Nigeria Stock Exchange from 2012 to 2019. This period is very important considering the recent changes in the reporting and audit regulatory landscape in form of IFRS and The Code 2018 which became effective during the period of the study. Fixed effect model estimate was adopted as it showed to be more appropriate than random effect estimate. Results of empirical model formulated to test determinant of audit quality provided evidence that the four variables of audit fee, audit independence, audit switching and audit credibility all have negative but insignificant effect on accrual level of selected firms listed in the Nigerian Stock Exchange. Thus it is concluded that the four variables of audit fee, audit independence, audit switching and audit firm size employed in the study by reducing accrual levels has positive effect on audit quality though their influence in not statistically significant.

The findings of this study agrees with Agency theory by Jensen and Meckling (1976) that third party assurance will reduce managers opportunistic behaviour, improve earnings quality by reducing accrual level. Thus owners of firm that are not allowed by regulation to directly express views on management reported figures can through external auditors prevent mangers from manipulating their earnings through quality of their audit. Thus better remuneration package for external auditors will not only bring out the best in them, it will reduce being easily manipulated with economic benefit by managers. Big audit firms have better capacity to face possible managerial pressures, which leads to deeper and stronger control over possible earnings management. Audit quality is measured with accrual quality developed by Dechow and Dichev (2002).

The study contributed to extant literature from Nigeria on using accrual quality in measuring audit quality. It also provided opportunity to compare the present results with the findings of extant studies. It is important to emphasise here that this study is based on the argument that if accrual level is low, then earning quality as well as audit quality is high. On the other hand, higher level of accruals is indicative of low earning and audit quality. This also indicate that management and auditor are biased on the earning figure reported in the financial statement. Low accrual level indicates that management is not able to exert its power over the auditor by being able to report on terms favourable to them.

ECRTD-UK: https://www.eajournals.org/

ULR: https://doi.org/10.37745/ejaafr.2013 


\section{Recommendation}

In the effort to enhance efficient functioning of the capital markets and develop Nigeria economy, there is need to restore investors' confidence to accounting numbers contained in the financial statements. Firms should understand that remunerating auditors very well apart from encouraging commitment to the audit service lead to better abilities to stand up to bribes or other pressure from managers.

In order to address concerns that have arisen on audit quality, there is need to enforce recent regulations toward audit firm rotation or switching after the ten years' period specified in the 2018 Code of corporate governance in order to reduce information risk and enhance audit quality.

Firms should review their policies particularly as it concerns their external auditors to ensure that there are no familiarity threats, real or perceived conflict of interest that will undermine their independence in carry out their services.

The study further recommends that regulatory agencies should make policies on other ways to address concerns about audit quality aside the variables of audit fee, audit independence, audit switching and audit size as they do not significantly promote audit quality.

\section{References}

Abdullah, W. Z., Ismail, S., \& Jamaluddin, N. (2008). The impact of board composition, ownership and ceo duality: The Malaysian evidence. Malaysian Accounting Review, 7(2), 17-28

Akrawah, D. O., Anichebe, A. S., \& Okunrobo, S. O. (2020). Determinants of auditor switching behaviour in Nigeria. Global Journal of Accounting and Economy Research, 1(2), 119144.

Aliu, M. M., Okpanachi, J., \& Mohammed, N. A. (2018). Audit fees and audit quality: A study of listed companies in the downstream Sector of Nigerian petroleum industry. Humanities, 6(2), 59-73.

AL-Qatamin, K. I., \& Salleh, Z. (2020). Audit quality: A literature overview and research synthesis. Journal of Business and Management, 22(2), 56-66.

Amahalu, N. N., Egolum, P. U., \& Obi, J. C. (2019). Effect of auditors' rotation on audit quality of quoted deposit money banks in Nigeria. In Managing Nigeria Economic Diversification: Lessons from Other Climes. Conference Proceeding 467-479

Amahalu, N., Okeke, M. N., \& Obi,C. J., (2018). Audit quality determinants: Evidence from quoted health care firms in Nigeria. International Journal of Academic Research in Accounting, Finance and Management Sciences, 7(4), 216-231.

Amahalu, N.N., \& Ezechukwu, B. O., (2017). Determinants of audit quality: Evidence from deposit money banks listed on Nigeria Stock Exchange. International Journal of Academic Research in Accounting, Finance and Management Sciences, 7(2), 117-130.

ECRTD-UK: https://www.eajournals.org/

ULR: https://doi.org/10.37745/ejaafr.2013 
Vol.10, No. 1, pp.1-24, 2022

Print ISSN: 2053-4086(Print),

Online ISSN: 2053-4094(Online)

Aroh, J. C., Odum, A. N., \& Odum, C. G. (2017). Determinants of auditor switch: evidence from quoted companies in nigeria. International Journal of Management Research and Business Strategy, 6(4), 1-16.

Ayorinde, B., \& Babajide, O. (2015). Audit tenure, rotation and accounting conservatism: empirical evidences from Nigeria. Journal of Business \& Financial Affairs, 4(03), 21670234.

Bala, H., Amran, N. A., \& Shaari, H. (2018). Audit fees and financial reporting quality: A study of listed companies in Nigeria. International Review of Management and Business Research, 7(2), 483-490.

Behn, B. K., Choi, J. H., \& Kang, T. (2008). Audit quality and properties of analyst earnings forecasts. The Accounting Review, 83(2), 327-349.

Bello, S. M., Ahmad, C. A., \& Yusof, M. N. Z. (2018). Internal audit quality dimensions and organizational performance in Nigerian federal universities: the role of top management support. Journal of Business \& Retail Management Research, 13(01), 156-170.

Chadegani, A. A., Mohamed, Z. M., \& Jari, A. (2011). The determinant factors of auditor switch among companies listed on Tehran Stock Exchange. International Research Journal of Finance and Economics, 80(80), 158-168.

Crucean, A. C., \& Hategan, C. D. (2019). The determinants factors on audit quality: A Theoretical Approach. Ovidius University Annals, Economic Sciences Series, 19(2), 702-710.

Dechow, P. M. and I. D. Dichev (2002). The quality of accruals and earnings: The role of accrual estimation errors. The Accounting Review 77(1): 35-59.

Dehkordi, H. F., \& Makarem, N. (2011). The effect of size and type of auditor on audit quality. International Research Journal of Finance and Economics, 80(2011), 121-137.

Edtiyarsih, D. D., Sudaryati, E., \& Budisusetyo, S. (2021). Interpretation of the traditional proverb "jer basuki mawa beya" on abnormal audit fees in the context of improving audit quality. The Indonesian Accounting Review, 11(1), 77-81.

El-Dyasty, M. M., \& Elamer, A. A. (2020). The effect of auditor type on audit quality in emerging markets: evidence from Egypt. International Journal of Accounting \& Information Management. doi:10.1108/ijaim-04-2020-0060

Enofe, A. O., Mgbame, C., Aderin, A., \& Ehi-Oshio, O. U. (2013). Determinants of audit quality in the Nigerian business environment. Research journal of finance and Accounting, 4(4), 36-43.

Enofe, A. O., Mgbame, C., Efayena, O., \& Edegware, J. (2014). Audit firm characteristics and auditing quality: The Nigerian experience. Research Journal of finance and Accounting, 5(6), 23-34.

Fauziyah, N., \& Darmayanti, N. (2021). The influence of audit costs, audit engagement and audit rotation on audit quality. Journal of Auditing, Finance, and Forensic Accounting, 9(1), 3443.

Febrianto, R., Dini, F., Audina, D., Yuskar, Y., \& Juita, V. (2017). The influence of pseudo auditor rotation on audit quality: New evidence. Australasian Accounting, Business and Finance Journal, 11(4), 71-85.

Frankel, R. M., Johnson, M. F., and Nelson, K. K. (2002). The relation between auditors' fees for nonaudit services and earnings management. The Accounting Review 77(s-1), 71-105.

ECRTD-UK: https://www.eajournals.org/

ULR: https://doi.org/10.37745/ejaafr.2013 
Geiger, M. \& D. Rama. (2006). Audit firm size and going-concern reporting accuracy. Accounting Horizons, 20(1), 1-17.

Ghebremichael, A. A. (2018). Determinants of audit service quality perceptions of supervisory directors in Dutch Corporations. Contemporary Management Research, 14(1), 53-84.

Hardiningsih, P., Januarti, I., Oktaviani, R. M., Srimindarti, C., Udin, U. (2019). Determinants of audit quality: An empirical insight from Indonesia. International Journal of Scientific \& Technology Research, 8(7), 570-578.

Haeridistia, N., \& Fadjarenie, A. (2019). The effect of independence, professional ethics \& auditor experience on audit quality. International Journal of Scientific \& Technology Research, 8 , $1-12$.

Hoitash, R., Markelevich, A., \& Barragato, C. A. (2007). Auditor fees and audit quality. Managerial Auditing Journal, 22(8), 761-786. doi:10.1108/02686900710819634

Hunt, J. O., Rosser, D. M., \& Rowe, S. P. (2020). Using machine learning to predict auditor switches: How the likelihood of switching affects audit quality among non-switching clients. Journal of Accounting and Public Policy, 106785.

Iryani, L. D. (2017). The effect of competence, independence, and professional auditors to audit quality. Journal of Humanities And Social Studies, 1(1), 1-4.

Jackson, A.B., Moldrich, M. and Roebuck, P. (2008). Mandatory audit firm rotation and audit quality", Managerial Auditing Journal, 23(5), 420-437.

Kighir, A. E. (2013). Mandatory audit firm rotation and auditor independence: empirical evidence from Nigerian listed banks. International Journal of Auditing Technology, 1(1), 5-17.

Knechel, W. R., Krishnan, G. V., Pevzner, M., Shefchik, L. B., \& Velury, U. K. (2013). Audit quality: Insights from the academic literature. Auditing: A Journal of Practice, 32(Supplement 1), 385-421.

Knechel, W. R., \& Vanstraelen, A. (2007). The relationship between auditor tenure and audit quality implied by going concern opinions. AUDITING: A journal of practice \& theory, 26(1), 113-131.

Khurana, I. K. and Raman, K. (2004). Litigation risk and the financial reporting credibility of Big 4 versus non-Big 4 audits: Evidence from Anglo-American countries. The Accounting Review, 79(2), 473-495.

Krishnan, J., \& Schauer, P. C. (2001). Differences in quality among audit firms. Journal of Accountancy, 192(1), 234-245.

Lamba, R. A., Seralurin, Y. C., Lamba, A., \& Pattiasina, V. (2020). The effect of auditor independence and ethics on auditor professional scepticism: Its implications for audit quality in Indonesia. International Journal of Innovation, Creativity and Change, 12(8), 383-396.

Leventis, S., Weetman, P., \& Caramanis, C. (2005). Determinants of audit report lag: Some evidence from the Athens Stock Exchange. International Journal of Auditing, 9(1), 45-58.

Liu, W., \& Liu, X. (2008). Auditor switching, earnings manipulation and auditor independence: Evidence from A-share listed companies in China. Frontiers of Business Research in China, 2(2), 283-302.

ECRTD-UK: https://www.eajournals.org/

ULR: https://doi.org/10.37745/ejaafr.2013 
Mohammed, a. M., \& Joshua, o. (2016). Auditor's characteristics and audit quality: a study of listed deposit money banks in nigeria. Kasu journal of accounting research and practice, 5(1), 84-107.

Mardijuwono, A. W., \& Subianto, C. (2018). Independence, professionalism, professional skepticism: The relation toward the resulted audit quality. Asian Journal of Accounting Research.

Masood, A., \& Afzal, M. (2016). Determinants of audit quality in Pakistan. Journal of Quality and Technology Management, 13(II), 25-49.

Nawangsari, F. Y., \& Iswajuni, I. (2019). The effects of auditor switching towards abnormal return in manufacturing company. Asian Journal of Accounting Research, 4(1), 157-168.

Octavia, E., \& Widodo, N. R. (2015). The effect of competence and independence of auditors on the audit quality. Research Journal of Finance and Accounting, 6(3), 189-194.

Odesa, J., \& Agubata, N. S. (2019). Audit selection regime and audit market concentration in a diversified economy: Evidence from Nigeria. Asian Journal of Science and Technology, 10(04), 9633-9638.

Ogoun, S., \& Perelayefa, O. G. (2020). Corporate governance and audit quality in Nigeria. American Journal of Industrial and Business Management, 10(2), 250-261.

Okaro, S. C., \& Okafor, G. O. (2013). Drivers of audit failure in Nigeria: Evidence from Cadbury (Nigeria) PLC. Research Journal of Finance and Accounting, 4(6), 1686-1697.

Okaro, S. C., \& Okafor, G. O. (2014). Board effectiveness and audit quality in Nigeria: A perspective study. International Journal of Management Sciences, 2(9), 406-17.

Okolie, A. O., \& Izedonmi, F. I. (2014). The Impact of audit quality on the share prices of quoted companies in Nigeria. Research Journal of Finance and Accounting, 5(8), 150-166.

Olabisi J., Kajola S.O., Abioro M.A., Oworu O.O. (2020) Determinants of audit quality: Evidence from Nigerian listed insurance companies. Journal of Volgograd State University. Economics, 22(2), 182-192.

Onwuchekwa, J. C., Erah, D., \& Izedonmi, F. (2012). Mandatory audit rotation and audit independence: Survey of Southern Nigeria. Research journal of finance and accounting, 3(7), 78-85.

Oyedokun, G. E., Yunusa, G. O., \& Adeyemo, K. A., (2018).Determinant of audit quality of quoted industrial goods sector in Nigeria. Research Journal of Finance and Accounting, 9(22), 7785.

Qawqzeh, H. K., Endut, W. A., Rashid, N., \& Dakhlallh, M. M. (2020). Impact of the external auditor's effectiveness on the financial reporting quality: the mediating effect of audit quality. Journal of Critical Reviews, 7(6), 1197-1208.

Rajgopal, S., Srinivasan, S., \& Zheng, X. (2021). Measuring audit quality. Review of Accounting Studies, 26(2), 559-619.

Reguera-Alvarado, N. de Fuentes, P., \& Laffarga, J. (2019). Do auditors mitigate earnings manageme nt during economic crisis? Revista de Contabilidad-Spanish Accounting Review, 22(1), 6-20.

Saputra, W. (2015). The impact of auditor's independence on audit quality: A theoretical approach. International journal of scientific \& technology research, 4(12), 348-353.

ECRTD-UK: https://www.eajournals.org/

ULR: https://doi.org/10.37745/ejaafr.2013 
Vol.10, No. 1, pp.1-24, 2022

Print ISSN: 2053-4086(Print),

Online ISSN: 2053-4094(Online)

Serly, V., \& Helmayunita, N. (2019). The Correlation of Audit Fee, Audit Quality and Integrity of Financial Statement. In 2nd Padang International Conference on Education, Economics, Business and Accounting (PICEEBA-2 2018), 67-72.

Soyemi, K. A., Olufemi, O. A., \& Adeyemi, S. B. (2020). External audit (or) quality and accrual earnings management: Further evidence from Nigeria. Malaysian Management Journal, 24, 31-56.

Stunda, R. (2012), Auditor switches in a post-sox environment, does the change in auditor mean a change in stock price? Journal of Business and Behavioral Sciences, 24(3), 65-71.

Subianto, C. (2018). Determinants of audit quality: An analysis of three points of international standards on auditing (ISA) and the identity of the auditor as an independent accountant. In Proceedings of the Journal of Contemporary Accounting and Economics Symposium 2018 on Special Session for Indonesian Study (JCAE 2018) - Contemporary Accounting Studies in Indonesia, 120-127.

Suseno, N. S. (2013). An empirical analysis of auditor independence and audit fees on audit quality. International Journal of Management and Business Studies, 3(3), 82-87.

Suyono, E. (2012). Determinant factors affecting the audit quality: An Indonesian perspective. Global Review of accounting and Finance, 3(2), 42-57.

Tobi, B. A., Osasrere, A. O., \& Emmanuel, U. (2016). Auditor's independence and audit quality: A study of selected deposit money banks in Nigeria. International Journal of Finance and Accounting, 5(1), 13-21.

Tiamiyu, M. A., Bamidele, I. L. O., \& Soyemi, K. A., (2019). Determinants of external auditor switching in Nigeria. Ilorin Journal of Finance, 3(1), 12 -23.

Weiner, J. (2012). Auditor Size vs. audit quality: An analysis of auditor switches. Accounting, 3, $1-32$.

Yanti, L. D., \& Wijaya, M. D. W. D. (2020). Influence of auditor switching, audit fee, tenure audit and company size to audit quality. eCo-Fin, 2(1), 152-158.

Yuniarti, R. (2011). Audit firm size, audit fee and audit quality. Journal of Global Management, 2(1), 84-97.

Yuniarti, R., Novriela, B. C., \& Rahmadona, F., (2021). The effect of audit fees and audit Tenure to audit quality. Psychology and Education Journal, 58(1), 6089-6099.

ECRTD-UK: https://www.eajournals.org/

ULR: https://doi.org/10.37745/ejaafr.2013 